\title{
Effects of Dietary Supplementation of Spirulina and Quercetin on Growth, Innate Immune Responses, Disease Resistance Against Edwardsiella tarda, and Dietary Antioxidant Capacity in the Juvenile Olive Flounder Paralichthys olivaceus
}

\author{
Sung-Sam Kim ${ }^{1, a}$, Samad Rahimnejad ${ }^{1}$, Kang-Woong Kim² ${ }^{2}$ Bong-Joo Lee ${ }^{2}$ and Kyeong-Jun Lee ${ }^{1,3, *}$ \\ ${ }^{1}$ Department of Marine Biomedical Science, Jeju National University, Jeju 690-756, Korea \\ ${ }^{2}$ Aquafeed Research Center, National Fisheries Research and Development Institute, Pohang 791-923, Korea \\ ${ }^{3}$ Marine and Environmental Research Institute, Jeju National University, Jeju 695-814, Korea \\ aPresent address: Feed/Animal Research Institute, CJ CheilJedang Corporation, Incheon 400-103, Korea
}

\begin{abstract}
A 10-week feeding trial was conducted to examine the effects of dietary spirulina and quercetin on growth, innate immunity, disease resistance and dietary antioxidant capacity in the juvenile olive flounder. Triplicate groups of fish (initial body weight, 2.9 $\pm 0.01 \mathrm{~g}$ ) were fed one of isonitrogenous ( $48 \%$ crude protein) and isocaloric $(17.4 \mathrm{MJ} / \mathrm{kg} \mathrm{DM})$ experimental diets containing $0 \%$ spirulina (as a control), $3.4 \%$ spirulina, or $6.8 \%$ spirulina with or without supplementation of $0.5 \%$ quercetin (designated as CON, SP3.4, SP6.8, and SP6.8 + Q, respectively) at a rate of 3\% body mass twice daily. Higher dietary antioxidant capacity was found with spirulina supplementation, and the highest value $(P<0.05)$ was obtained with SP6.8 + Q diet. At the end of the feeding trial, no significant effects were observed on growth performance, body composition and disease resistance against Edwardsiella tarda. Lysozyme activity was significantly increased by spirulina supplementation $(P<0.05)$, and the highest value was observed in the group fed SP6.8 + Q diet. Also, significantly higher respiratory burst activity $(P<0.05)$ was found in SP3.4 group. According to the results of this study, dietary supplementation of $3.4 \%$ spirulina may enhance innate immunity of olive flounder.
\end{abstract}

Key words: Olive flounder, Spirulina, Quercetin, Growth, Innate immunity, Edwardsiella tarda challenge

\section{Introduction}

Aquaculture remains one of the fastest-growing animal food-producing sectors, accounting for almost half of total food fish and substitutes for wild fish and plants (Food and Agriculture Organization of the United Nations, 2010). However, disease has been a primary constraint to the aquaculture industry, imposing severe losses on farming facilities all over the world.

Antibiotic drugs have the capacity to kill or inhibit the growth of micro-organisms. However, the use of antibiotics to control fish disease needs to be restricted due to the emergence of drug-resistant bacteria and concerns about environmental hazards and food safety (Hernández Serrano, 2005). The future development of aquaculture greatly depends on the development of alternative feed ingredients that can provide higher resistance against pathogens.

Marine macro- and microalgae have been supplemented in diets for different cultured fish species and have been reported to have positive effects on growth performance, feed utiliza-
Open Access http://dx.doi.org/10.5657/FAS.2013.0007

This is an Open Access article distributed under the terms of the Creative Commons Attribution Non-Commercial License (http://creativecommons. org/licenses/by-nc/3.0/) which permits unrestricted non-commercial use, distribution, and reproduction in any medium, provided the original work is properly cited. pISSN: 2234-1749 eISSN: 2234-1757
Received 15 May 2012; Revised 20 December 2012

Accepted 26 December 2012

*Corresponding Author

E-mail: kjlee@jejunu.ac.kr 
tion, lipid metabolism, carcass quality, stress tolerance and disease resistance (Mustafa and Nakagawa, 1995; Nakagawa and Montgomery, 2007; Güroy et al., 2011). Microalgal species are of great value because of their high bioactive materials content, including polyunsaturated fatty acids, $\beta$-carotene and other pigments (antioxidants) (Cohen and Vonshak, 1991; Mahajan and Kamat, 1995; Bhat and Madyastha, 2000; Reddy et al., 2000), sulfated polysaccharides (anti-virals) and sterols (antimicrobials) (Ötleş and Pire, 2001).

Spirulina has been one of the most widely used microalgal species in aquafeeds due to its high contents of protein, vitamins, essential amino acids, minerals, essential fatty acids and antioxidant pigments such as carotenoids (Nakagawa and Montgomery, 2007). Also, its immunomodulatory activity has been shown in animal experiments, which demonstrated its enhancement of phagocytic and natural killer activities (Qureshi and Ali, 1996). Several studies have been conducted to investigate the effects of spirulina on growth, nutrient utilization and immune responses of various fish species, including rainbow trout Oncorhynchus mykiss (Matty and Smith, 1978), red sea bream Pagrus major (Mustafa et al., 1997), common carp Cyprinus carpio (Nandeesha et al., 1998), tilapia Oreochromis niloticus (Takeuchi et al., 2002), white sturgeon Acipenser transmontanus (Palmegiano et al., 2008), Mekong giant catfish Pangasianodon gigas (Tongsiri et al., 2010), and African sharptooth catfish Clarias gariepinus (Promya and Chitmanat, 2011).

Quercetin is a flavonoid found in fruits, vegetables and other medicinal and aromatic plants (Rupasinghe, 2008). Its antioxidant and anti-inflammatory activities have been demonstrated in in vitro experiments. Due to its antioxidant activity, it can be used in fish oil storage in aquaculture (Nieto et al., 1993).

Olive flounder Paralichthys olivaceus is one of the most important fish species for marine aquaculture in Asian countries, and it has been successfully cultured in Korea, Japan and China (Kang et al., 2008; Castaño-Sánchez et al., 2010). Because of the importance of this species for Korean mariculture and large economic losses caused by edwardsiellosis in culture facilities (Galindo-Villegas et al., 2006), a feeding trial was undertaken to examine the effects of dietary spirulina and quercetin supplementation on growth performance, nonspecific immune responses, and disease resistance of the olive flounder against Edwardsiella tarda.

\section{Materials and Methods}

\section{Fish}

Juvenile olive flounder were transported from a private hatchery (Chang-Hae Fisheries Co., Jeju Island, Korea) to the Marine and Environmental Research Institute of Jeju National University (Jeju Island). All the fish were acclimated to the experimental conditions for 2 weeks and were fed a basal experimental diet. A flow-through system was used, and sandfiltered seawater was supplied at a rate of $3 \mathrm{~L} / \mathrm{min}$. Aeration was provided by a central aeration system and air stones. Water was exchanged every $24 \mathrm{~h}$ to remove fecal materials. The rearing water temperature during the experiment varied from $15^{\circ} \mathrm{C}$ to $19^{\circ} \mathrm{C}$, and the photoperiod was maintained on a $12: 12$ light:dark schedule.

\section{Experimental design}

At the end of the acclimation period, 20 randomly selected fish (initial body weight, $2.9 \pm 0.01 \mathrm{~g}$ ) were introduced into each tank (capacity $35 \mathrm{~L}$ ) and supplied with seawater at a flow rate of $3 \mathrm{~L} / \mathrm{min}$. Four isonitrogenous (48\% crude protein) and isocaloric (17.4 MJ/kg DM) experimental diets were prepared and formulated to contain 0\% spirulina Spirulina pacifica (Cyanotech Ltd., Kailua-Kona, HI, USA), 3.4\% spirulina, $6.8 \%$ spirulina, or $6.8 \%$ spirulina plus $0.5 \%$ quercetin (designated as CON, SP3.4, SP6.8, and SP6.8 + Q, respectively). The formulations and proximate composition of the experimental diets are shown in Table 1. All dry ingredients

Table 1. Formulation and proximate composition of the experimental diets (\% DM)

\begin{tabular}{lrrrr}
\hline \multirow{2}{*}{ Ingredients } & \multicolumn{4}{c}{ Diets } \\
\cline { 2 - 5 } & CON & SP3.4 & SP6.8 & SP6.8 + Q \\
\hline White fish meal & 52.0 & 49.4 & 46.8 & 46.8 \\
Soybean meal & 6.0 & 6.0 & 6.0 & 6.0 \\
Corn gluten meal & 6.0 & 6.0 & 6.0 & 6.0 \\
Spirulina & 0.0 & 3.4 & 6.8 & 6.8 \\
Quercetin & 0.0 & 0.0 & 0.0 & 0.5 \\
Wheat flour & 21.5 & 21.5 & 21.5 & 21.5 \\
Mineral mix & 0.5 & 0.5 & 0.5 & 0.5 \\
Vitamin mix & 0.5 & 0.5 & 0.5 & 0.5 \\
Squid liver oil & 10.0 & 10.0 & 10.0 & 10.0 \\
CMC & 1.0 & 1.0 & 1.0 & 1.0 \\
Cellulose & 2.5 & 1.7 & 0.9 & 0.4 \\
Proximate composition & & & & \\
Dry matter (\%) & 94.8 & 91.4 & 93.8 & 91.8 \\
Protein (\% DM) & 47.9 & 48.0 & 47.4 & 48.2 \\
Lipid (\% DM) & 15.7 & 15.5 & 15.4 & 15.5 \\
Ash (\% DM) & 9.0 & 9.2 & 9.4 & 9.5 \\
Gross energy" & 17.5 & 17.7 & 17.8 & 17.8 \\
\hline CON & & & \\
\hline
\end{tabular}

CON, 0\% spirulina; SP3.4, 3.4\% spirulina; SP6.8, 6.8\% spirulina; SP6.8 + Q, $6.8 \%$ spirulina plus $0.5 \%$ quercetin.

"Spirulina was purchase from Cyanotech Ltd., Kailua-Kona, $\mathrm{HI}$, USA, ${ }^{\dagger}$ Mineral premix (g/kg of mixture): $\mathrm{MgSO}_{4} \cdot 7 \mathrm{H}_{2} \mathrm{O}, 80.0 ; \mathrm{NaH}_{2} \mathrm{PO}_{4} \cdot 2 \mathrm{H}_{2} \mathrm{O}, 370.0 ; \mathrm{KCl}$, 130.0; ferric citrate, $40.0 ; \mathrm{ZnSO}_{4} \cdot 7 \mathrm{H}_{2} \mathrm{O}, 20.0$; Ca-lactate, 356.5; $\mathrm{CuCl}_{2}, 0.2$; $\mathrm{AlCl}_{3} .6 \mathrm{H}_{2} \mathrm{O}, 0.15 ; \mathrm{Na}_{2} \mathrm{Se}_{2} \mathrm{O}_{3}, 0.01 ; \mathrm{MnSO}_{4} \cdot \mathrm{H}_{2} \mathrm{O}, 2.0 ; \mathrm{CoCl}_{2} \cdot 6 \mathrm{H}_{2} \mathrm{O}, 1.0$, ${ }^{\prime}$ Vitamin premix (g/kg of mixture): L-ascorbic acid, 121.2; DL-a tocopheryl acetate, 18.8; thiamin hydrochloride, 2.7; riboflavin, 9.1; pyridoxine hydrochloride, 1.8; niacin, 36.4; Ca-o-pantothenate, 12.7; myo-inositol, 181.8; o-biotin, 0.27; folic acid, 0.68 ; $\mathrm{p}$-aminobezoic acid, 18.2; menadione, 1.8; retinyl acetate, 0.73; cholecalficerol, 0.003; cyanocobalamin, $0.003,{ }^{5}$ Carboxymethyl cellulose, "Estimated energy was determined by using values of $16.7 \mathrm{~kJ} / \mathrm{g}$ protein or carbohydrate and $37.7 \mathrm{~kJ} / \mathrm{g}$ fat for dietary ingredients (Lee and Putnam, 1973). 
were thoroughly mixed, and after addition of fish oil and 30\% double distilled water, the mixture was extruded through a meat chopper machine (SMC-12; Kuposlice, Busan, Korea) in $3.0 \mathrm{~mm}$ diameter. The pellets were subsequently crushed into desirable particle sizes and stored at $-20^{\circ} \mathrm{C}$ until use. The energy value of each diet was estimated based on mammalian physiological fuel values, i.e., $16.7 \mathrm{~kJ} / \mathrm{g}$ proteins or carbohydrates and $37.7 \mathrm{~kJ} / \mathrm{g}$ lipids (Lee and Putnam, 1973). The experiment was conducted in triplicate. The fish were fed at a feeding rate of $3 \%$ body mass twice daily (08:00 and 18:00 h) for 10 weeks. Fish growth was measured at 2-week intervals, and the feeding rate was adjusted accordingly. All fish were starved for $24 \mathrm{~h}$ and anaesthetized with MS-222 (200 mg/L) prior to handling for weighing or blood sampling.

\section{Antioxidant capacity assay}

The antioxidant capacity of the experimental diets was determined by 1,1-diphenyl-2-picrylhydrazyl (DPPH) radical scavenging assay, as described by Brand-Williams et al. (1995) with some modifications. Diets (2 g) were homogenized in $20 \mathrm{~mL}$ of aqueous methanol (80\%) and kept at room temperature for $10 \mathrm{~min}$. The homogenates were centrifuged $\left(5,000 \mathrm{rpm}, 4^{\circ} \mathrm{C}, 10 \mathrm{~min}\right)$ and filtered through a $0.45-\mathrm{nm}$ syringe filter (Whatman, Inc., Clifton, NJ, USA) prior to the assay. Filtered extract $(100 \mu \mathrm{L})$ was added to a $1.5-\mathrm{mL}$ cuvette, and then $900 \mu \mathrm{L}$ of DPPH methanolic solution $(100 \mu \mathrm{M})$ was added to give a final volume of $1 \mathrm{~mL}$. The absorbance of the mixture was recorded at $517 \mathrm{~nm}$ at $1-\mathrm{min}$ intervals for $10 \mathrm{~min}$ using a spectrophotometer (Genesys 10UV; Thermo Spectronic, Rochester, NY, USA). The antioxidant capacity of the extract against DPPH radicals was calculated as percent inhibition as follows:

$$
\text { Percent inhibition }=\left[\left(\mathrm{A}_{0}-\mathrm{A}_{\mathrm{s}}\right) / \mathrm{A}_{0}\right] \times 100
$$

, where $\mathrm{A}_{0}$ and $\mathrm{A}_{\mathrm{s}}$ are the absorbances of the sample after 0 and $\mathrm{S}$ min, respectively.

\section{Sampling and analyses}

All the fish in each tank were weighed and counted at the beginning and end of the experiment for calculation of growth parameters and survival. Also, at the end of the feeding trial, blood samples were collected via the caudal vein from three randomly captured fish from each tank (nine fish per treatment) for measurement of hematological and immunological parameters. Analyses of the moisture and ash contents of the experimental diets and whole-body samples were performed by standard procedures (Association of Official Analytical Chemists, 1995). Crude protein was measured using an automatic Kjeltec 2300 Analyzer Unit (FOSS, Hoeganaes, Sweden). Crude lipid was determined using the Soxhlet Extraction System C-SH6 (Korea).

\section{Hematological and immunological assays}

The hematocrit was determined by the microhematocrit technique (Brown, 1980). Concentrations of hemoglobin, aspartate aminotransferase (AST), alanine aminotransferase (ALT), cholesterol and triglycerides were determined using an automated blood analyzer (SLIM; SEAC, Inc., Florence, Italy).

A turbidometric assay was used to determine lysozyme activity in serum by the method described by Zhou et al. (2006) with slight modifications. Briefly, Micrococcus lysodeikticus (0.75 mg/mL) (Sigma-Aldrich Chemie GmbH, Munich, Germany) was suspended in sodium phosphate buffer $(0.1 \mathrm{M}, \mathrm{pH}$ 6.4). Then, $200 \mu \mathrm{L}$ of suspension was placed in each well of 96-well plates, and $20 \mu \mathrm{L}$ of serum was subsequently added. The reduction in absorbance at $570 \mathrm{~nm}$ of each sample was recorded after incubation at room temperature for 0 and 30 $\min$. A reduction in absorbance of $0.001 / \mathrm{min}$ was regarded as one unit of lysozyme activity.

Oxidative radical production by phagocytes during respiratory burst was measured by the nitro-blue-tetrazolium (NBT) assay described by Anderson and Siwicki (1995). Briefly, blood and NBT (0.2\%) (Sigma, St. Louis, MO, USA) were mixed in equal proportions $(1: 1)$ and incubated for $30 \mathrm{~min}$ at room temperature. Then, $50 \mu \mathrm{L}$ was removed and dispensed into glass tubes. Next, $1 \mathrm{~mL}$ of dimethylformamide (Sigma) was added, and the tubes were centrifuged at 2,000 $\mathrm{g}$ for 5 min. Finally, the optical density of each supernatant was measured at $540 \mathrm{~nm}$ using a spectrophotometer (Genesys $10 \mathrm{UV}$, Rochester, NY, USA). Dimethylformamide was used as a blank.

\section{Challenge test}

E. tarda, isolated from diseased flounders of a fish farm in Jeju Island, was used as the pathogenic agent to investigate the susceptibility of fish fed the experimental diets to bacterial challenge. At the end of the experiment, 10 healthy fish of similar sizes were selected from each tank (30 fish per treatment) and intraperitoneally injected with $1 \mathrm{~mL}$ of $E$. tarda suspension containing $3 \times 10^{8}$ bacteria cells $/ \mathrm{mL}$. The pathogenic dose of bacterium had previously been determined in a preliminary test using fish of a similar size. After injection, the fish were transferred to tanks (capacity $30 \mathrm{~L}$ ), and their mortality was monitored and recorded for 10 days.

\section{Statistical analysis}

Data were subjected to one-way analysis of variance (ANOVA) using SPSS version 11.0 (SPSS Inc., Chicago, IL, USA). Significant differences among groups were identified by Duncan's multiple test $(P<0.05)$. Data are presented as the mean \pm SD. Percentage data were arcsine transformed before analysis. 


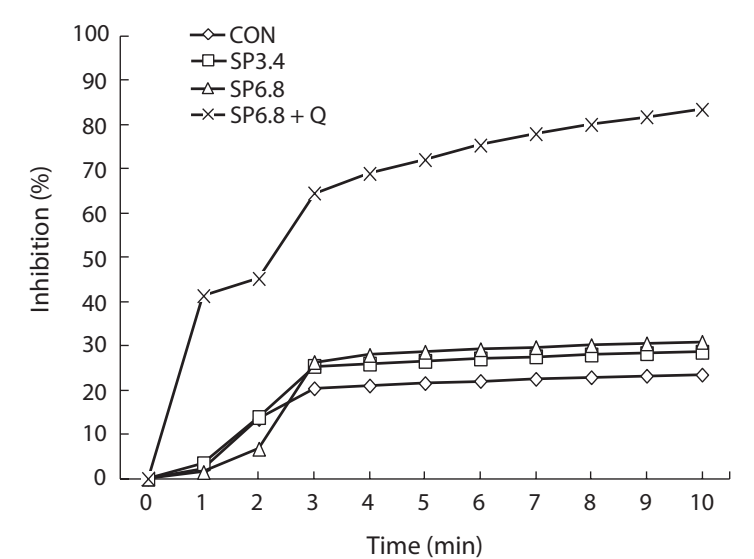

Fig. 1. The antioxidant capacity of experimental diets evaluated by DPPH radical scavenging assay. CON, $0 \%$ spirulina; SP3.4, 3.4\% spirulina; SP6.8, $6.8 \%$ spirulina; SP6.8 + Q, $6.8 \%$ spirulina plus $0.5 \%$ quercetin.
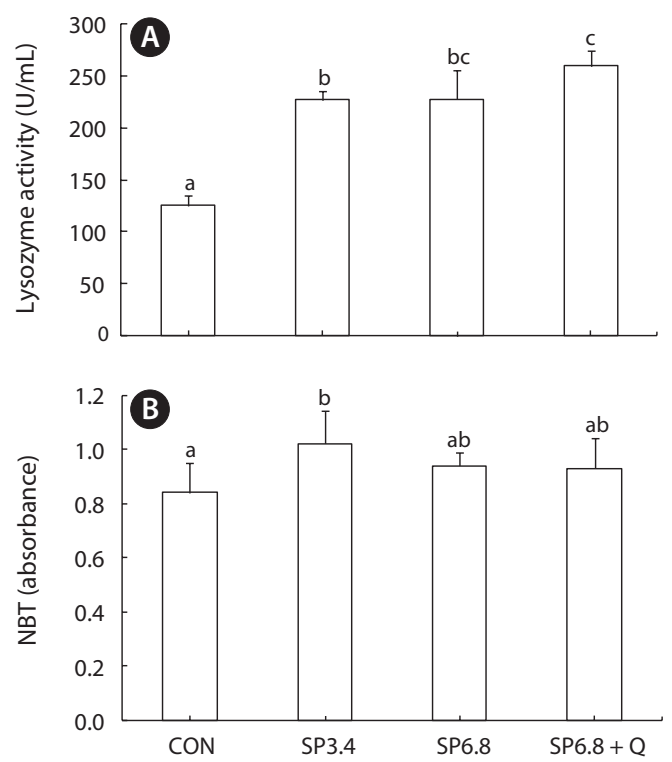

Fig. 2. Effects of dietary spirulina and quercetin on lysozyme (A) and nitro-blue-tetrazolium (NBT) (B) activities of juvenile olive flounder Paralichthys olivaceus fed the experimental diets for 10 weeks. Different letters signify statistical differences $(P<0.05)$ between groups. CON, $0 \%$ spirulina; SP3.4, 3.4\% spirulina; SP6.8, 6.8\% spirulina; SP6.8 + Q, 6.8\% spirulina plus $0.5 \%$ quercetin.

\section{Results}

Dietary supplementation of spirulina resulted in slightly higher antioxidant capacity, and the highest significant $(P<$ 0.05) value was for the SP6.8 + Q diet (Fig. 1).

The growth performance of juvenile olive flounder fed the experimental diets is presented in Table 2. Although growth performance and feed utilization efficiency were positively affected by spirulina supplementation, no significant differences were observed among treatments. The survival rate of fish was approximately $100 \%$ regardless of dietary treatments.

No significant differences in whole-body proximate composition were detected among the experimental groups (Table 3). However, slightly higher crude protein and ash levels were found in fish fed spirulina-supplemented diets.

There were no significant effects on hematocrit, hemoglobin, AST and ALT levels (Table 4). However, the serum cholesterol level was significantly decreased in SP3.4 and SP6.8 groups compared with the control group (Table 4). Also, significant reductions were found in total triglyceride levels in fish fed spirulina-supplemented diets compared with the control group, but quercetin supplementation had no significant effect (Table 4).

Serum lysozyme activity was significantly increased in fish fed spirulina-containing diets compared with those fed the control diet (Fig. 2A). Also, significantly higher respiratory burst activity was observed in SP3.4 group (Fig. 2B).

Disease resistance of the fish was not significantly affected by dietary treatments; however, the control group exhibited lower resistance against $E$. tarda compared with the other experimental groups (Fig. 3).

\section{Discussion}

In the present study, dietary spirulina did not significantly affect the growth performance of olive flounder. Similarly, no significant effects have been reported on growth performance in common carp Cyprinus carpio (Nandeesha et al., 1998), catla Catla catla (Nandeesha et al., 2001), Nile tilapia

Table 2. Growth performance and survival of juvenile olive flounder Paralichthys olivaceus fed the experimental diets for 10 weeks

\begin{tabular}{lcrrr}
\hline Diets & CON & SP3.4 & SP6.8 & SP6.8+Q \\
\hline WG (g) & $13.05 \pm 3.68$ & $13.70 \pm 1.33$ & $13.77 \pm 1.08$ & $14.27 \pm 2.46$ \\
SGR (\%) & $1.05 \pm 0.14$ & $1.08 \pm 0.05$ & $1.08 \pm 0.04$ & $1.09 \pm 0.07$ \\
PER $^{\dagger}$ & $1.68 \pm 0.35$ & $1.68 \pm 0.13$ & $1.75 \pm 0.10$ & $1.71 \pm 0.13$ \\
FCR $^{\S}$ & $1.27 \pm 0.30$ & $1.24 \pm 0.09$ & $1.18 \pm 0.07$ & $1.21 \pm 0.09$ \\
FI (g/g BW) & $15.88 \pm 1.52$ & $16.88 \pm 0.37$ & $16.26 \pm 0.56$ & $17.18 \pm 1.77$ \\
Survival (\%) & $100 \pm 0.0$ & $98.33 \pm 2.89$ & $100 \pm 0.0$ & $100 \pm 0.0$ \\
\hline
\end{tabular}

Values are presented as mean \pm SD. No significant differences were found between diets for any growth parameter $(P<0.05)$.

CON, 0\% spirulina; SP3.4, 3.4\% spirulina; SP6.8, $6.8 \%$ spirulina; SP6.8 + Q, 6.8\% spirulina plus $0.5 \%$ quercetin.

"Weight gain (WG) = final mean body weight - initial mean body weight, ${ }^{\dagger}$ Specific growth rate $(\mathrm{SGR})=[(\log$ final body weight - log initial body weight)/ days $] \times 100,{ }^{\ddagger}$ Protein efficiency ratio (PER) = wet weight gain/total protein given, ${ }^{5}$ Feed conversion ratio (FGR) = dry feed fed/wet weight gain, "Feed intake $(\mathrm{Fl})=$ dry feed consumed $(\mathrm{g}) /$ body weight $(\mathrm{g})$. 


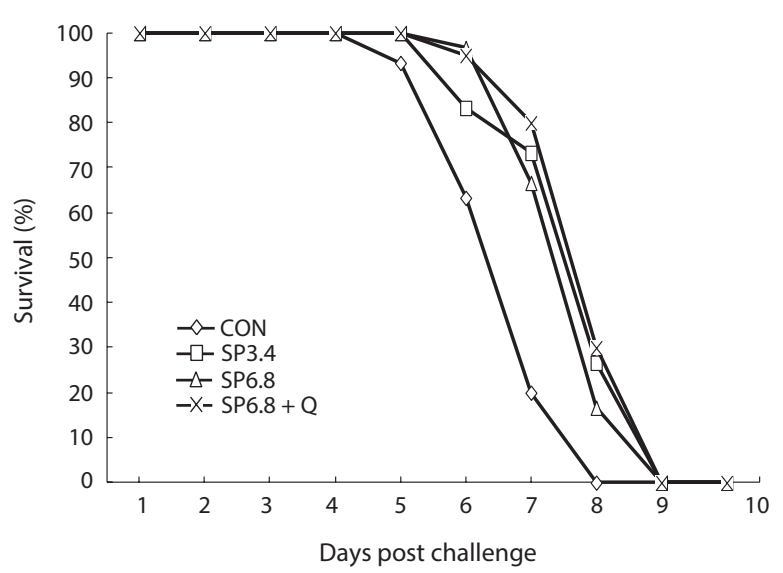

Fig. 3. Survival rate of juvenile olive flounder Paralichthys olivaceus fed the experimental diets after challenge with Edwardsiella tarda. CON, 0\% spirulina; SP3.4, 3.4\% spirulina; SP6.8, 6.8\% spirulina; SP6.8 + Q, 6.8\% spirulina plus $0.5 \%$ quercetin.

Oreochromis niloticus (Takeuchi et al., 2002), white sturgeon Acipenser transmontanus (Palmegiano et al., 2008), Mekong giant catfish (Tongsiri et al., 2010), and African sharptooth catfish Clarias gariepinus (Promya and Chitmanat, 2011). By contrast, the results of other studies revealed positive effects of spirulina on the growth of other fish species, including the nibbler Girella punctata Gray (Nakazoe et al., 1986), striped jack Pseudocaranx dentex (Watanabe et al., 1990), red sea bream Pagrus major (Mustafa et al., 1994), rohu Labeo rohita (Nandeesha et al., 2001), Nile tilapia (Lu et al., 2004), Siberian sturgeon Acipenser baeri (Palmegiano et al., 2005), Pla Pho Pangasius bocourti (Meng-Umphan, 2009), and Nile tilapia (Abdel-Tawwab and Ahmad, 2009), a red tilapia hybrid (Oreochromis mossambicus $\times$ O. niloticus) (Ungsethaphand et al., 2010), and a mixed breed catfish (Clarias macrocephalus $\times$ Clarias gariepinus) (Burchell) (Promkunthong and Pipattanwattankhul, 2005).

Abdel-Tawwab and Ahmad (2009) attributed the growth enhancement of Nile tilapia fed spirulina to improved feed intake and digestibility and suggested that high contents of several nutrients including vitamins and minerals may aid its growth-enhancing effects. Alternatively, growth improvement by spirulina may be a result of increased fish appetite (Nandeesha et al., 1998). The variation in spirulina's effects on fish growth performance may be due to the different nutritive values of spirulina species used in experiments (Nandeesha et al., 1998). Also, Takeuchi et al. (2002) declared that differences in the effects of spirulina on fish growth may be due to differences in the chemical compositions of experimental diets.

In the present study, the whole-body composition of fish was not significantly influenced by spirulina. As shown in the previous studies with silver seabream, Siberian sturgeon and red tilapia hybrid (El-Sayed, 1994; Palmegiano et al., 2005; Ungsethaphand et al., 2010). However, the results of some other studies revealed significant changes in whole-body crude protein (Nandeesha et al., 2001; Abdel-Tawwab and Ahmad, 2009; Promya and Chitmanat, 2011), crude lipid (Mustafa et al., 1995; Nandeesha et al., 1998, 2001; Abdel-Tawwab and Ahmad, 2009), ash (Nandeesha et al., 2001; Tongsiri et al., 2010), and moisture contents (Tongsiri et al., 2010; Promya and Chitmanat, 2011) of fish after spirulina administration.

The effects of spirulina on whole-body protein and lipid

Table 3. Whole body composition of juvenile olive flounder Paralichthys olivaceus fed the experimental diets for 10 weeks

\begin{tabular}{lrrrr}
\hline Diets & CON & SP3.4 & SP6.8 & SP6.8 + Q \\
\hline Moisture & $76.2 \pm 2.1$ & $75.78 \pm 0.2$ & $76.0 \pm 0.1$ & $75.8 \pm 1.1$ \\
Crude protein & $15.6 \pm 0.5$ & $16.31 \pm 0.2$ & $16.2 \pm 0.4$ & $16.2 \pm 0.7$ \\
Crude lipid & $3.7 \pm 1.0$ & $3.03 \pm 0.5$ & $3.2 \pm 0.8$ & $3.3 \pm 0.5$ \\
Ash & $2.8 \pm 0.2$ & $3.06 \pm 0.1$ & $3.2 \pm 0.3$ & $2.8 \pm 0.2$ \\
\hline
\end{tabular}

Data are presented as mean \pm SD. No significant differences were found between treatment groups $(P<0.05)$.

CON, $0 \%$ spirulina; SP3.4, 3.4\% spirulina; SP6.8, $6.8 \%$ spirulina; SP6.8 $+Q, 6.8 \%$ spirulina plus $0.5 \%$ quercetin.

Table 4. Hematological parameters of juvenile olive flounder Paralichthys olivaceus fed the experimental diets for 10 weeks

\begin{tabular}{lcccc}
\hline Diets & CON & SP3.4 & SP6.8 & SP6.8 + Q \\
\hline Ht (\%) & $19.3 \pm 2.6$ & $20.5 \pm 1.3$ & $16.7 \pm 3.1$ & $19.5 \pm 5.9$ \\
Hb (g/dL) & $3.1 \pm 1.2$ & $3.7 \pm 0.5$ & $3.8 \pm 0.5$ & $3.3 \pm 0.2$ \\
AST (U/L) & $101 \pm 22$ & $73 \pm 25$ & $67 \pm 37$ & $93 \pm 83$ \\
ALT (U/L) & $287 \pm 240$ & $169 \pm 149$ & $78 \pm 94$ & $133 \pm 85$ \\
Cholesterol (mg/dL) & $217 \pm 7^{\mathrm{b}}$ & $177 \pm 5^{\mathrm{a}}$ & $177 \pm 14^{\mathrm{a}}$ & $201 \pm 19^{\mathrm{ab}}$ \\
Triglyceride (mg/dL) & $6.7 \pm 0.2^{\mathrm{b}}$ & $4.4 \pm 1.3^{\mathrm{a}}$ & $3.7 \pm 0.6^{\mathrm{a}}$ & $4.1 \pm 0.8^{\mathrm{a}}$ \\
\hline
\end{tabular}

Data are presented as mean \pm SD. Values in the same row having different superscript letters are significantly different $(P<0.05)$.

CON, 0\% spirulina; SP3.4, 3.4\% spirulina; SP6.8, 6.8\% spirulina; SP6.8 + Q, 6.8\% spirulina plus $0.5 \%$ quercetin; $\mathrm{Ht}$, hematocrit; Hb, hemoglobin; AST, aspartare aminotransferase (one unit regarded as the amount of enzyme which oxidizes one $\mu \mathrm{mol} / \mathrm{L}$ of $\mathrm{NADH}$ per minute); ALT, alanine aminotransferase. 
contents are correlated with their synthesis and accumulation rate in muscle, as well as the growth rate of the organisms (Smith, 1981; Fauconneau, 1984; Soivio et al., 1989; AbdelTawwab et al., 2006; Abdel-Tawwab and Ahmad, 2009). Nandeesha et al. (2001) stated that the effect of dietary spirulina on whole-body lipid content is dependent on species of the spirulina used. Also, its effect on whole-body lipid content differs among species (Nandeesha et al., 1998). In some studies, a raw spirulina source was used. It has been shown that rearing conditions can affect crude protein and lipid contents of spirulina, resulting in different effects on body composition of fish compared with those of commercial spirulina powder (Takeuchi et al., 2002).

It has been shown that spirulina has hypocholesterolemic and hepato-preservative properties (Khan et al., 2005; Peiretti and Meineri, 2011). Such effects have not been investigated in fish species. In this study, we examined the effects of spirulina on serum cholesterol and triglyceride levels, as well as AST and ALT levels, and found significant reductions in cholesterol and triglyceride levels. However, although the levels of AST and ALT were decreased by spirulina supplementation, no significant differences were observed among treatments.

Fish mostly rely on innate immunity in comparison to mamals (Swain et al., 2007). Accordingly, great attention has been focused on the use of dietary bioactive materials to stimulate innate immunity. The immunomodulatory activity of spirulina has been attributed to its content of C-phycocyanin (Venkataraman, 1997). In our study, significantly higher lysozyme activities were detected for both supplementation levels of spirulina, and the highest activity was observed in SP6.8 + Q group. Similarly, Promya and Chitmanat (2011) showed a significant increase in serum lysozyme activity in African sharptooth catfish Clarias gariepinus fed $3 \%$ or $5 \%$ dietary spirulina. Also, significantly higher respiratory burst activity was found in olive flounders fed SP3.4 diet in agreement with the results of studies by Watanuki et al. (2006) and AbdelTawwab and Ahmad (2009) on the common carp Cyprinus carpio and Nile tilapia, respectively.

The results of challenge test showed that spirulina or quercetin supplementation could not provide protection against E. tarda and could only delay fish mortality. By contrast, increased disease resistance of Nile tilapia and rohu was reported against Aeromonas hydrophila when challenged after spirulina administration (Abdel-Tawwab and Ahmad, 2009; Andrews et al., 2011). The lack of protection against bacterial challenge in this study, unlike in previous studies, may be due to the lower levels of dietary spirulina supplementation or the species of the spirulina.

Spirulina contains numerous bioactive materials including phytopigments, such as phycobilins, phycocyanin, allophycocyanin and xanthophylls, which make it a potential natural dietary source of antioxidants (Miranda et al., 1998; Bhat and Madyastha, 2000; Wang et al., 2007; Bermejo et al., 2008). In the present study, we investigated the antioxidant capacities of experimental diets supplemented with spirulina, and the results showed positive effects.

In conclusion, dietary supplementation of spirulina approximately over $3 \%$ can increase the innate immunity of olive flounder. But, the supplemental level of $3-7 \%$ is not likely to improve the growth performance of the fish rearing in low water temperature.

\section{Acknowledgements}

This work was supported by the research grant from the Chuongbong Academic Research Fund of Jeju National University (2010).

\section{References}

Abdel-Tawwab M and Ahmad MH. 2009. Live spirulina (Arthrospira platensis) as a growth and immunity promoter for Nile tilapia, Oreochromis niloticus (L.), challenged with pathogenic Aeromonas hydrophila. Aquac Res 40, 1037-1046. http://dx.doi. org/10.1111/j.1365-2109.2009.02195.x.

Abdel-Tawwab M, Khattab YAE, Ahmad MH and Shalaby AME. 2006. Compensatory growth, feed utilization, whole-body composition and hematological changes in starved juvenile Nile tilapia, Oreochromis niloticus (L.). J Appl Aquac 18, 17-36. http://dx.doi. org/10.1300/J028v18n03_02.

Anderson DP and Siwicki AK. 1995. Basic haematology and serology for fish health programs. In: Diseases in Asian Aquaculture II. Shariff M, Arthur JR and Subasinghe JP, eds. Fish Health Section, Asian Fisheries Society, Manila, PH, pp. 185-202.

Andrews SR, Sahu NP, Pal AK, Mukherjee SC and Kumar S. 2011. Yeast extract, brewer's yeast and spirulina in diets for Labeo rohita fingerlings affect haemato-immunological responses and survival following Aeromonas hydrophila challenge. Res Vet Sci 91, 103109. http://dx.doi.org/10.1016/j.rvsc.2010.08.009.

Association of Official Analytical Chemists. 1995. Official Methods Analysis. 16th ed. Association of Official Analytical Chemists, Arlington, VA, US.

Bermejo P, Piñero E and Villar ÁM. 2008. Iron-chelating ability and antioxidant properties of phycocyanin isolated from a protean extract of Spirulina platensis. Food Chem, 110, 436-445. http://dx.doi. org/10.1016/j.foodchem.2008.02.021.

Bhat VB and Madyastha KM. 2000. C-phycocyanin: a potent peroxyl radical scavenger in vivo and in vitro. Biochem Biophys Res Commun 275, 20-25. http://dx.doi.org/10.1006/bbrc.2000.3270.

Brand-Williams W, Cuvelier ME and Berset C. 1995. Use of a free radical method to evaluate antioxidant activity. LWT Food Sci Technol 28, 25-30. http://dx.doi.org/10.1016/S0023-6438(95)80008-5.

Brown BA. 1980. Hematology: Principles and Procedures. Lea and Febiger, Philadelphia, PA, US, pp. 71-112.

Castaño-Sánchez C, Fuji K, Ozaki A, Hasegawa O, Sakamoto T, Morishima K, Nakayama I, Fujiwara A, Masaoka T, Okamoto H, 
Hayashida K, Tagami M, Kawai J, Hayashizaki Y and Okamoto N. 2010. A second generation genetic linkage map of Japanese flounder (Paralichthys olivaceus). BMC Genomics 11, 554. http:// dx.doi.org/10.1186/1471-2164-11-554.

Cohen Z and Vonshak A. 1991. Fatty acid composition of Spirulina and Spirulina-like cyanobacteria in relation to their chemotaxonomy. Phytochemistry 30, 205-206. http://dx.doi.org/10.1016/00319422(91)84125-C.

El-Sayed AFM. 1994. Evaluation of soybean meal, spirulina meal and chicken offal meal as protein sources for silver seabream (Rhabdosargus sarba) fingerlings. Aquaculture 127, 169-176. http://dx.doi. org/10.1016/0044-8486(94)90423-5.

Fauconneau B. 1984. The measurements of whole body protein synthesis in larval and juvenile carp (Cyprinus carpio). Comp Biochem Physiol B 78, 845-850. http://dx.doi.org/10.1016/03050491(84)90196-2.

Food and Agriculture Organization of the United Nations. 2010. The State of World Fisheries and Aquaculture. Fisheries and Aquaculture Department, Food and Agriculture Organization of the United Nations, Rome, IT.

Galindo-Villegas J, Fukada H, Masumoto T and Hosokawa H. 2006. Effect of dietary immunostimulants on some innate immune responses and disease resistance against Edwardsiella tarda infection in Japanese flounder (Paralichthys olivaceus). Suisan Zoshoku 54, 153-162.

Güroy D, Güroy B, Merrifield DL, Ergün S, Tekinay AA and Yiğit M. 2011. Effect of dietary Ulva and Spirulina on weight loss and body composition of rainbow trout, Oncorhynchus mykiss (Walbaum), during a starvation period. J Anim Pysiol Anim Nutr (Berl) 95, 320-327. http://dx.doi.org/10.1111/j.1439-0396.2010.01057.x.

Hernández Serrano P. 2005. Responsible Use of Antibiotics in Aquaculture. FAO Fisheries Technical Paper. No. 469. FAO, Rome, IT.

Kang JH, Kim WJ and Lee WJ. 2008. Genetic linkage map of olive flounder, Paralichthys olivaceus. Int J Biol Sci 4, 143-149.

Khan Z, Bhadouria P and Bisen PS. 2005. Nutritional and therapeutic potential of Spirulina. Curr Pharm Biotechnol 6, 373-379. http:// dx.doi.org/10.2174/138920105774370607.

Lee DJ and Putnam GB. 1973. The response of rainbow trout to varying protein/energy ratios in a test diet. J Nutr 103, 916-922.

Lu J, Takeuchi T and Satoh H. 2004. Ingestion and assimilation of three species of freshwater algae by larval tilapia Oreochromis niloticus. Aquaculture 238, 437-449. http://dx.doi.org/10.1016/j.aquaculture.2004.05.002.

Mahajan G and Kamat M. 1995. $\gamma$-Linolenic acid production from Spirulina platensis. Appl Microbiol Biotechnol 43, 466-469. http:// dx.doi.org/10.1007/BF00218450.

Matty A and Smith P. 1978. Evaluation of a yeast, a bacterium and an alga as a protein source for rainbow trout. I. Effect of protein level on growth, gross conversion efficiency and protein conversion efficiency. Aquaculture 14, 235-246. http://dx.doi.org/10.1016/00448486(78)90097-2.

Meng-Umphan K. 2009. Growth performance, sex hormone levels and maturation ability of Pla Pho (Pangasius bocourti) fed with Spirulina supplementary pellet and hormone application. Int J Agric
Biol 11, 458-462.

Miranda MS, Cintra RG, Barros SB and Mancini Filho J. 1998. Antioxidant activity of the microalga Spirulina maxima. Braz J Med Biol Res 31, 1075-1079. http://dx.doi.org/10.1590/S0100879X1998000800007.

Mustafa MG and Nakagawa H. 1995. A review: dietary benefits of algae as an additive in fish feed. Isr J Aquac-Bamidgeh 47, 155-162.

Mustafa MG, Umino T and Nakagawa H. 1994. The effect of Spirulina feeding on muscle protein deposition in red sea bream, Pagrus major. J Appl Ichthyol 10, 141-145. http://dx.doi. org/10.1111/j.1439-0426.1994.tb00153.x.

Mustafa MG, Wakamatsu S, Takeda TA, Umino T and Nakagawa H. 1995. Effects of algae meal as feed additive on growth, feed efficiency, and body composition in red sea bream. Fish Sci 61, 25-28.

Mustafa MG, Umino T and Nakagawa H. 1997. Limited synergistic effect of dietary Spirulina on vitamin C nutrition of red sea bream Pagrus major. J Mar Biotechnol 5, 129-132.

Nakagawa H and Montgomery WL. 2007. Algae. In: Dietary Supplements for the Health and Quality of Cultured Fish. Nakagawa H, Sato $\mathrm{M}$ and Gatlin DM 3rd, eds. CABI International, Cambridge, MA, US, pp. 133-168.

Nakazoe J, Kimura S, Yokoyama M and Iida H. 1986. Effect of supplementation of alga to the diets on the growth and body composition of nibbler, Girella punctata Grey. Bull Tokai Reg Fish Res Lab 120, 43-51.

Nandeesha MC, Gangadhara B, Varghese TJ and Keshavanath P. 1998. Effect of feeding Spirulina platensis on the growth, proximate composition and organoleptic quality of common carp, Cyprinus carpio L. Aquac Res 29, 305-312. http://dx.doi.org/10.1046/ j.1365-2109.1998.00163.x.

Nandeesha MC, Gangadhara B, Manissery JK and Venkataraman LV. 2001. Growth performance of two Indian major carps, catla (Catla catla) and rohu (Labeo rohita) fed diets containing different levels of Spirulina platensis. Bioresour Technol 80, 117-120. http:// dx.doi.org/10.1016/S0960-8524(01)00085-2.

Nieto S, Garrido A, Sanhueza J, Loyola LA, Morales G, Leighton F, Valenzuela A. 1993. Flavonoids as stabilizers of fish oil: an alternative to synthetic antioxidants. J Am Oil Chem Soc 70, 773-778. http://dx.doi.org/10.1007/BF02542599.

Ötleş S and Pire R. 2001. Fatty acid composition of Chlorella and Spirulina microalgae species. J AOAC Int 84, 1708-1714.

Palmegiano GB, Agradi E, Forneris G, Gai F, Gasco L, Rigamonti E, Sicuro B and Zoccarato I. 2005. Spirulina as a nutrient source in diets for growing sturgeon (Acipenser baeri). Aquac Res 36, 188195. http://dx.doi.org/10.1111/j.1365-2109.2005.01209.x.

Palmegiano GB, Gai F, Daprà F, Gasco L, Pazzaglia M and Peiretti PG. 2008. Effects of Spirulina and plant oil on the growth and lipid traits of white sturgeon (Acipenser transmontanus) fingerlings. Aquac Res 39, 587-595. http://dx.doi.org/10.1111/j.13652109.2008.01914.x.

Peiretti PG and Meineri G. 2011. Effects of diets with increasing levels of Spirulina platensis on the carcass characteristics, meat quality and fatty acid composition of growing rabbits. Livest Sci 140, 218224. http://dx.doi.org/10.1016/j.livsci.2011.03.031. 
Promkunthong W and Pipattanwattankhul A. 2005. Results of Spirulina alga on growth and antibody levels in mixed breed Catfish (Clarias macrocephalus $\times$ Clarias gariepinus (Burchell). Songkhlanakarin Technol Sci J 27, 115-132.

Promya J and Chitmanat C. 2011. The effects of Spirulina platensis and Cladophora algae on the growth performance, meat quality and immunity stimulating capacity of the African Sharptooth Catfish (Clarias gariepinus). Int J Agric Biol 13, 77-82.

Qureshi MA and Ali RA. 1996. Spirulina platensis exposure enhances macrophage phagocytic function in cats. Immunopharmacol Immunotoxicol 18, 457-463. http://dx.doi.org/10.3109/08923979609 052747.

Reddy CM, Bhat VB, Kiranmai G, Reddy MN, Reddanna P and Madyastha KM. 2000. Selective inhibition of cyclooxygenase-2 by C-phycocyanin, a biliprotein from Spirulina platensis. Biochem Biophys Res Commun 277, 599-603. http://dx.doi.org/10.1006/ bbrc.2000.3725.

Rupasinghe HPV. 2008. The role of polyphenols in quality, postharvest handling, and processing of fruits. In: Postharvest Biology and Technology of Fruits, Vegetables and Flowers. Paliyath G, Murr DP, Handa AK and Lurie S, eds. Wiley-Blackwell Publishing, Hoboken, NJ, US, pp. 260-281.

Smith MAK. 1981. Estimation of growth potential by measurement of tissue protein synthetic rates in feeding and fasting rainbow trout, Salmo gairdneri Richardson. J Fish Biol 19, 213-220. http://dx.doi. org/10.1111/j.1095-8649.1981.tb05825.x.

Soivio A, Niemistö M and Bäckström M. 1989. Fatty acid composition of Coregonus muksun Pallas: changes during incubation, hatching, feeding and starvation. Aquaculture 79, 163-168. http://dx.doi. org/10.1016/0044-8486(89)90457-2.

Swain P, Dash S, Sahoo PK, Routray P, Sahoo SK, Gupta SD, Meher PK and Sarangi N. 2007. Non-specific immune parameters of brood Indian major carp Labeo rohita and their seasonal variations.
Fish Shellfish Immunol 22, 38-43. http://dx.doi.org/10.1016/j. fsi.2006.03.010.

Takeuchi T, Lu J, Yoshizaki G and Satoh S. 2002. Effect on the growth and body composition of juvenile tilapia Oreochromis niloticus fed raw Spirulina. Fish Sci 68, 34-40. http://dx.doi.org/10.1046/ j.1444-2906.2002.00386.x.

Tongsiri S, Mang-Amphan K and Peerapornpisal Y. 2010. Effect of replacing fishmeal with Spirulina on growth, carcass composition and pigment of the Mekong giant catfish. Asian J Agric Sci 2, 106110.

Ungsethaphand T, Peerapornpisal Y, Whangchai N and Sardsud U. 2010. Effect of feeding Spirulina platensis on growth and carcass composition of hybrid red tilapia (Oreochromis mossambicus $\times O$. niloticus). Maejo Int J Sci Technol 4, 331-336.

Venkataraman LV. 1997. Spirulina platensis (Arthospira): physiology, cell biology and biotechnologym, edited by Avigad Vonshak. J Appl Phycol 9, 295-296. http://dx.doi.org/10.1023/A:1007911009912.

Wang L, Pan B, Sheng J, Xu J and Hu Q. 2007. Antioxidant activity of Spirulina platensis extracts by supercritical carbon dioxide extraction. Food Chem 105, 36-41. http://dx.doi.org/10.1016/j.foodchem.2007.03.054.

Watanabe T, Liao WL, Takeuchi T and Yamamoto H. 1990. Effect of dietary Spirulina supplementation on growth performance and flesh lipids of cultured striped jack. J Tokyo Univ Fish 77, 231-239.

Watanuki H, Ota K, Tassakka ACMAR, Kato T and Sakai M. 2006. Immunostimulant effects of dietary Spirulina platensis on carp, Cyprinus carpio. Aquaculture 258, 157-163. http://dx.doi.org/10.1016/j. aquaculture.2006.05.003.

Zhou J, Song XL, Huang J and Wang XH. 2006. Effects of dietary supplementation of A3 $\alpha$-peptidoglycan on innate immune responses and defense activity of Japanese flounder (Paralichthys oilvaceus). Aquaculture 251, 172-181. 